\title{
INFLUENCE OF PLANTING DATE, PLANT AGE, DISTRIBUTION PATTERN AND CONTROL OF MAIZE LEAFMINER, Pseudonapomyza spicata MALL. (DIPTERA: AGROMYZIDAE) ON MAIZE PLANTS AT KAFR EL-SHEIKH REGION

\author{
EI-Samahy, M. F. M. ; A. A. Taman and Fathia A. Salem
} \\ Plant Protection Res. Inst., Agric. Res. Center, Sakha, Dokki, Egypt.
}

\begin{abstract}
The study was conducted at Sakha Agriculture Research Station Farm and the laboratory of field crop pests research department, Plant Protection Research Institute (PPRI) at Sakha to evaluate the influence of planting date and age of maize plants on the degree of infestation by Pseudonapomyza spicata Mall. and study also distribution pattern of this insect mines on maize (Zea mays L.) leaves. Data showed that this leaf miner infested maize plants of July plantation as highest, followed by maize plants of June and September plantations. However, maize sown during April or May was insect-free. The leaves of 30-days old were the most infested with the leafminer, $P$. spicata followed by those of 20 - and 10 -day old. Older than one month, maize plants were not preferred by $P$. spicata. The infestations with $P$. spicata were concentrated in the lower leaves, and then the damage became slighter toward to the top of the plant. The insecticide, Gaucho $7 \%$ WP used at rate of 7 or $14 \mathrm{~g} / \mathrm{kg}$ maize seed as seed-coating effectively reduced the infestation with $P$. spicata. This treatment is less harmful to natural enemies, because the insecticide is used with seeds not as a spray onto maize plants.
\end{abstract}

Keywords: Maize leafminer, planting date, distribution pattern, control

\section{INTRODUCTION}

Maize (Zea mays L.) is one of the most important cereal crops in Egypt, and allover the world, representing a main source of energy for human and animals (Abd El-Ghany, 2004). Maize is ranked as the third cereal crop in the world (FAO, 1988). Also, in Egypt maize is the third cereal crop after rice and wheat .

Maize plants are subject to attacks of several insect species during the growing season. The most serious insect pests that attack maize plants namely; the greater sugarcane borer, Sesamia cretica Led. (Lepidoptera: Noctuidae); the European corn borer, Ostrinia nubilalis (Hub.) (Lepidoptera: Crambidae); are of great economic importance, because their infestation can intensively reduce maize production El-Mashaly (2009). Leafminer, Pseudonapomyza spicata Mall. (Diptera: Agromyzidae) has rarely attracted the attention of entomologists. Haikal (1969), Aly (1971), Abul-Nasr et al. (1975) and Abd El-Ghany (2004) surveyed maize and sorghum as of $P$. spicata.

Because $P$. spicata had little attention of the hosts investigators, the current study was undertaken to be a stand by if this insect becomes of economic importance. 


\section{MATERIALS AND METHODS}

Efficiency of planting dates and age of maize plants on the infestation by maize leafminer, Pseudonapomyza spicata:

This investigate was carried out at the Experimental Farm of Sakha Agriculture Research Station, Kafr El-Sheikh Governorate and the laboratory of Field Crop Pests Research Department, Plant Protection Research Institute (PPRI) at Sakha for two successive seasons; 2010 and 2011 to evaluate the effect of maize planting date and age of maize plants on the degree of infestation by Pseudonapomyza spicata. Maize cultivar, Giza 2 was sown on; $20^{\text {th }}$ April, $15^{\text {th }}$ May, $1^{\text {st }}$ June, $10^{\text {th }}$ July and $10^{\text {th }}$ September. Sampling started 10 days after sowing, and continued at 10-day intervals till the leafminer infestation became negligible. Each sample consisted of 20 plants ( 5 plants $\times 4$ replicates), in which number of infested plants, mines and larvae were recorded. Throughout the maize season, all recommended cultural practices were followed, but without any pesticides. Recording infestation parameters was applied on maize plants standing in the field.

Distribution pattern of Pseudonapomyza spicata mines on maize leaves:

This experiment was conducted during 2010 and 2011 maize seasons. Maize plants of 30-day old (almost, each plant has 8-9 leaves) were examined. This plant age coincides with the peak of $P$. spicata infestation (Aly, 1971). The lowest five leaves (repeated 4 times) were inspected since they have most of maize leafminer infestation. Each leaf was theoretically divided into three parts; base, middle and tip, and each part was examined for $P$. spicata mines.

Control of maize leafminer, Pseudonapomyza spicata by using soilincorporated and seed-coated insecticides:

Carbofuran is a carbamate insecticide. Carbamates are synthetic derivatives of physostigmine which is a bean alkaloid (calabar bean, Physostigma venerosum). Carbofuran was registered for the first time in 1969 in the USA. In chemical terms it is a 2,3-dihydro-2,2-dimethyl-7-benzofuranyl methylcarbamate and its molecular formula is $\mathrm{C}_{12} \mathrm{H}_{15} \mathrm{NO}_{3}$ (Goad et al., 2004). Imidacloprid is a neonicotinoid insecticide in the chloronicotinyl nitroguanidine chemical family (Wismer, 2004 and Tomlin, 2006). The International Union of Pure and Applied Chemistry (IUPAC) name is 1-(6chloro-3-pyridylmethyl)- $\mathrm{N}$-nitroimidazolidin-2-ylideneamine and the Chemical Abstracts Service (CAS) registry number is 138261-41-3 and its molecular formula as $\mathrm{C}_{9} \mathrm{H}_{10} \mathrm{CIN}_{5} \mathrm{O}_{2}$ (Tomlin, 2006).

- Molecular Structure

Carbofuran<smiles>CNC(=O)OC1C=CCC2CC(C)(C)OC21</smiles><smiles>O=[N+]([O-])NC1=NCCN1Cc1ccc(Cl)nc1</smiles>

Imidacloprid 
The experimental field had 40 plots (each $42 \mathrm{~m}^{2}=10$ rows $\times 6 \mathrm{~m}$ long). Five treatments, excluding the check, were replicated four times. Four insecticides were incorporated into the soil. Carbofuran compounds manufactured in three commercial products; Furazid $10 \%$ G, Furadan $10 \% \mathrm{G}$ and Bilarfuran $10 \% \mathrm{G}$, the fourth one was Diazinon (Diazinox $5 \% \mathrm{G}$ ). Each of the above-mentioned insecticides was evaluated at two rates, 4 and $6 \mathrm{~kg} / \mathrm{fed}$. In addition, imidalcorpid (Gaucho $70 \%$ WP, 7 and $14 \mathrm{~g} / \mathrm{kg}$ seeds) was used as a seed coating insecticide at sowing. Numbers of mines and larvae/5 maize plants were recorded when maize aged 30-day old.

The obtained data were statistically analyzed using Least Significant differences (LSD) at $5 \%$ level (Duncan,1955) to reveal the significance among the involved varieties.

\section{RESULTS AND DISCUSION}

Influence of planting date and age of maize plants on the infestation by maize leafminer, Pseudonapomyza spicata:

It was found that both April and May plantations were free from infestations. Data presented in Table (1) show the effect of sowing date and plant age on the degree of infestation by $P$. spicata in maize leaves in 2010 season. All criteria of $P$. spicata infestation were highest in July plantation compared with June and September plantations. In July plantation, the mean of infested plants was 17.00 , mines was 445.69 having 328.44 larvae per 20 maize plants. The corresponding values were lower in September plantation; $12.75,81.06$ and 49.94 , while those of June plantation were the lowest; 4.81, 10.44 and 6.25. When the age of maize plants were considered, it was found that 30-day old maize plants had the highest damage by $P$. spicata followed by 20-day, 40-day and then 10-day old plants.

Table (1): Influence of maize sowing date and age of maize plants on the infestation with Pseudonapomyza spicata Mall. per 20 plants during 2010 maize season at Kafr El-Sheikh region.

\begin{tabular}{|c|c|c|c|c|c|c|c|c|c|c|c|c|}
\hline \multirow[b]{2}{*}{$\begin{array}{l}\text { Plant } \\
\text { age } \\
\text { (day) }\end{array}$} & \multicolumn{3}{|c|}{ June plantation } & \multicolumn{3}{|c|}{ July plantation } & \multicolumn{3}{|c|}{ September plantation } & \multicolumn{3}{|c|}{ Average } \\
\hline & 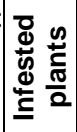 & $\stackrel{\mathscr{E}}{\stackrel{\Xi}{\Sigma}}$ & 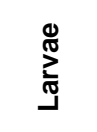 & 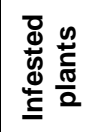 & 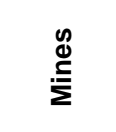 & 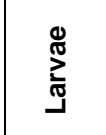 & 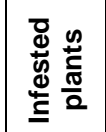 & $\stackrel{\text { g }}{\stackrel{\Phi}{\Sigma}}$ & 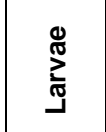 & 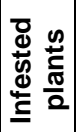 & 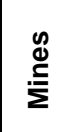 & 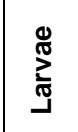 \\
\hline 10 & $3.00 \mathrm{~b}$ & $5.00 \mathrm{c}$ & $3.75 \mathrm{c}$ & $11.00 \mathrm{c}$ & $89.00 \mathrm{c}$ & $59.00 \mathrm{c}$ & $9.50 \mathrm{c}$ & $25.75 \mathrm{c}$ & $15.50 \mathrm{c}$ & 7.83 & 39.92 & 26.08 \\
\hline 20 & $3.50 \mathrm{~b}$ & $10.75 b$ & $4.75 \mathrm{~b}$ & $21.25 \mathrm{a}$ & $186.50 \mathrm{~b}$ & $110.50 \mathrm{~b}$ & $13.75 \mathrm{~b}$ & $56.50 \mathrm{bc}$ & $32.75 \mathrm{bc}$ & 12.83 & 84.58 & 49.67 \\
\hline 30 & $8.75 \mathrm{a}$ & $20.50 \mathrm{a}$ & $12.50 \mathrm{a}$ & $21.25 \mathrm{a}$ & $1354.50 \mathrm{a}$ & $1034.75 a$ & $16.25 \mathrm{a}$ & $177.50 \mathrm{a}$ & $111.50 \mathrm{a}$ & 15.42 & 527.50 & 386.25 \\
\hline 40 & $4.00 \mathrm{~b}$ & $5.50 \mathrm{c}$ & $4.00 \mathrm{c}$ & $14.50 \mathrm{~b}$ & $152.75 \mathrm{bc}$ & & $11.50 \mathrm{bc}$ & $64.50 \mathrm{~b}$ & $40.00 \mathrm{a}$ & 10.00 & 74.25 & 51.17 \\
\hline Av. & 4.81 & 10.44 & 6.25 & 17.00 & 445.69 & 328.44 & 12.75 & 81.06 & 49.94 & 11.52 & 181.56 & 128.29 \\
\hline
\end{tabular}

Means followed by the same letter are not significantly different at $5 \%$ level (DMRT)

Statistical analysis showed that maize plants of 30-day old had significantly the highest infestation with maize leafminer, $P$. spicata compared with the other ages. The least significant infestation was detected in plants of 10-day old. However, 30-day old plant had 15.42 infested plants, 527.50 mines and 386.25 larvae per 20 plants compared to $12.83,84.58$ and 
49.67 in 20-day old plants. The least damaged plants were those of 10-day old, having 7.83 infested plants, 39.92 mines and 26.08 larvae per 20 maize plants.

Data of the same investigation in 2011 maize season are presented in Table (2). Although the overall damage of $P$. spicata was lower in 2011 than that of 2010, the same trend was detected. July plantation received the highest infestation; 12.31 infested plants, 279.18 mines and 164.19 larvae per 20 maize plants, followed by September plantation; 8.00, 20.25 and 9.75, and then June plantation; $3.00,5.56$ and 3.69 for the infested plants, mines and larvae, respectively. Significantly, the highest infestation was that of 30day old maize plants, while the lowest one was that of 10-day.

Table (2): The influences of maize sowing date and age of maize plants on the infestation with Pseudonapomyza spicata Mall. per 20 plants during 2011 maize season at Kafr El-Sheikh region.

\begin{tabular}{|c|c|c|c|c|c|c|c|c|c|c|c|c|}
\hline \multirow{2}{*}{ 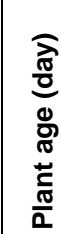 } & \multicolumn{3}{|c|}{ June plantation } & \multicolumn{3}{|c|}{ July plantation } & \multicolumn{3}{|c|}{$\begin{array}{l}\text { September } \\
\text { plantation }\end{array}$} & \multicolumn{3}{|c|}{ Average } \\
\hline & 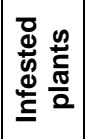 & $\stackrel{g}{\underline{\Phi}}$ & 志 & 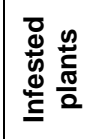 & $\stackrel{g}{\Xi}$ & $\frac{\mathbb{\pi}}{2}$ & 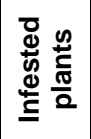 & $\stackrel{g}{\stackrel{g}{\Sigma}}$ & 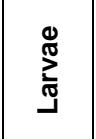 & 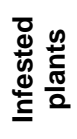 & $\stackrel{\text { g }}{\stackrel{\Phi}{\Sigma}}$ & 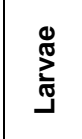 \\
\hline 10 & $1.25 \mathrm{c}$ & $1.25 \mathrm{c}$ & $1.25 \mathrm{c}$ & $7.75 \mathrm{c}$ & $55.75 \mathrm{bc}$ & $37.50 \mathrm{bc}$ & $4.75 \mathrm{c}$ & $9.50 \mathrm{c}$ & $5.25 \mathrm{c}$ & 4.58 & 22.17 & 14.67 \\
\hline 20 & $2.25 \mathrm{~b}$ & $5.25 b$ & $3.50 \mathrm{~b}$ & $15.25 b$ & $121.75 b$ & $88.75 b$ & $9.25 b$ & $26.50 \mathrm{~b}$ & $11.75 \mathrm{~b}$ & 8.92 & 51.50 & 34.67 \\
\hline 30 & $6.00 \mathrm{a}$ & $12.50 \mathrm{a}$ & $7.75 \mathrm{a}$ & $17.50 \mathrm{a}$ & $899.00 \mathrm{a}$ & $513.75 \mathrm{a}$ & $12.50 \mathrm{a}$ & $37.75 \mathrm{a}$ & $18.75 a$ & 12.00 & 316.42 & 180.00 \\
\hline 40 & $2.50 \mathrm{~b}$ & $3.25 \mathrm{bc}$ & $2.25 \mathrm{~b}$ & $8.75 \mathrm{c}$ & $40.00 \mathrm{c}$ & $16.75 \mathrm{c}$ & $5.50 \mathrm{c}$ & $7.25 \mathrm{c}$ & $3.25 \mathrm{~d}$ & 5.28 & 16.38 & 7.33 \\
\hline Av. & 3.00 & 5.56 & 3.69 & 12.31 & 279.13 & 164.19 & 8.00 & 20.25 & 9.75 & 7.70 & 101.62 & \begin{tabular}{|l|}
59.17 \\
\end{tabular} \\
\hline
\end{tabular}

The highest damage was detected in 30-day old plants (12.00 infested plants, 316.42 mines and 180.00 larvae per 20 maize plants), followed by those of 20-day, 40-day and then 10-day old plants which exhibited the lowest infestation.

The current study is not in agreement with those of Haikal (1969) who detected infestation with $P$. spicata on maize sown in March or April. However, results of Aly (1971) and Abd El-Ghany (2004) agree with the current results, as they showed a high insect infestation in 30-day old plants.

Distribution pattern of $P$. spicata mines on maize leaves:

In 2010 season (Table 3 ), the second lower leaf had significantly the highest level of mines (12.67 per leaf), followed by the lowest leaf (10.33), third leaf (9.50), fourth (4.92) and then fifth one (3.42 mines).

Table (3): Distribution of Pseudonapomyza spicata Mall. mines/leaf on different parts of maize leaves during $\mathbf{2 0 1 0}$ maize season.

\begin{tabular}{|l|c|c|c|c|}
\hline \multicolumn{1}{|c|}{ Leaf number } & Base of leaf & Mid of leaf & Tip of leaf & Average \\
\hline $\mathbf{1}$ (lowest) & $8.75 \mathrm{~b}$ & $10.75 \mathrm{~b}$ & $11.50 \mathrm{ab}$ & 10.33 \\
$\mathbf{2}$ & $12.00 \mathrm{a}$ & $12.50 \mathrm{a}$ & $13.50 \mathrm{a}$ & 12.67 \\
$\mathbf{3}$ & $2.75 \mathrm{c}$ & $10.75 \mathrm{~b}$ & $15.00 \mathrm{a}$ & 9.50 \\
$\mathbf{4}$ & $2.50 \mathrm{c}$ & $3.50 \mathrm{c}$ & $8.75 \mathrm{~b}$ & 4.92 \\
$\mathbf{5}$ (highest) & $2.25 \mathrm{~d}$ & $2.25 \mathrm{~d}$ & $5.75 \mathrm{c}$ & 3.42 \\
\hline Average & 5.65 & 7.95 & 10.90 & \\
\hline
\end{tabular}

Means followed by the same letter are not significantly different at $5 \%$ level (DMRT) 
On the other hand, the tip of the leaf blade was most subjected to maize leafminer damage (10.90 mines) followed by the mid of leaf (7.95 mines) and then the base of leaf (5.65 mines).

Data of 2011 season took the same trend (Table 4). The second lower leaf had significantly the highest infestation, followed by the lowest one, while leaf five (the highest) had significantly the slightest infestation. Also, tip of the leaf was the most subject to maize leafminer infestation, while the base of leaf was the least.

Table (4): Distribution of Pseudonapomyza spicata Mall. mines/leaf on different parts of maize leaves during 2011 maize season.

\begin{tabular}{|l|c|c|c|c|}
\hline \multicolumn{1}{|c|}{ Leaf number } & Base of leaf & Mid of leaf & Tip of leaf & Average \\
\hline $\mathbf{1}$ (lowest) & $8.00 \mathrm{~b}$ & $10.25 \mathrm{~b}$ & $11.75 \mathrm{~b}$ & 10.00 \\
$\mathbf{2}$ & $11.25 \mathrm{a}$ & $12.25 \mathrm{a}$ & $13.50 \mathrm{a}$ & 12.33 \\
$\mathbf{3}$ & $2.75 \mathrm{c}$ & $8.50 \mathrm{~b}$ & $12.75 \mathrm{~b}$ & 8.00 \\
$\mathbf{4}$ & $2.50 \mathrm{c}$ & $3.25 \mathrm{c}$ & $6.75 \mathrm{c}$ & 4.17 \\
$\mathbf{5}$ (highest) & $2.25 \mathrm{~d}$ & $2.25 \mathrm{c}$ & $4.00 \mathrm{~d}$ & 2.83 \\
\hline Average & 5.35 & 7.30 & 9.75 & \\
\hline
\end{tabular}

Means followed by the same letter are not significantly different at $5 \%$ level (DMRT)

Control of maize leafminer, $P$. spicata by using soil-incorporated and seed-coated insecticides:

Data presented in Tables (5 and 6 ) show the effect of five insecticides, each at two doses, applied as soil-incorporated or seed-coated, on the infestation with maize leafminer, P. spicata during 2010 and 2011 maize seasons.

In 2010 season (Table 5), untreated plots had significantly the highest insect damage; 250.00 mines and 191.00 larvae/5 maize plants. The applications of insecticides reduced both number of mines and larvae in maize leaves. Gaucho proved significantly to be the best treatment at both rates ( 7 and $14 \mathrm{~g} / \mathrm{one} \mathrm{kg}$ seeds) eliminating 63.40 and $80.00 \%$ of mines, and 69.63 and $86.26 \%$ of larvae, respectively. The second rank was occupied by Bilarfuradan ( $6 \mathrm{~kg} / \mathrm{fed}$.), with values of 64.20 and $64.79 \%$ reductions in mines and larvae, respectively. On the other hand, the lowest effective insecticides were Diazinox ( $4 \mathrm{~kg}$ ) which resulted 42.50 and $51.18 \%$ removal of mines and larvae, respectively, followed by Furazid $(4 \mathrm{~kg})$.

In 2011 season (Table 6), the same trend was obtained. Significantly, the most effective insecticides were Gaucho (14 g/kg seed) with 73.75 and $80.06 \%$ removal of mines and larvae, respectively. The respective values of Bilarfuradan (6 kg/fed) were 75.00 and $60.97 \%$ mines and larvae, respectively. Both Diazinox (at both rates) and Furazid $(4 \mathrm{~kg})$ were the least effective insecticides inducing the least reduction values.

Results of both seasons show the high effectiveness of Gaucho and Bilarfuradan against the maize leafminer, P. spicata. Since Gaucho is used as seed dressing during maize sowing, this insecticide could be seen as promising against the insects attacking maize plants during the seedling stage, besides its efficacy against the target insect, $P$. spicata. Abul-Nasr et al. (1975) proved that Diazinon 40 WP (2.5 kg/fed), Gardona 75 WP (2 $\mathrm{Kg} / \mathrm{fed})$ and Dursban $85 \mathrm{WP}(2.5 \mathrm{~kg} / \mathrm{fed})$ were efficient phosphorus 
El-Samahy, M. F. M. et al.

compounds for controlling $P$. spicata. Also, these results are in agreement with those of Abd El- Ghany (2004).

Table (5): Effect of soil-incorporated and seed-coated insecticides on Pseudonapomyza spicata/5 maize plants during 10 July plantation (2010 season).

\begin{tabular}{|c|c|c|c|c|c|}
\hline \multirow[b]{2}{*}{ Treatment } & \multirow[b]{2}{*}{ Dose/fed } & \multicolumn{2}{|c|}{ Mines } & \multicolumn{2}{|c|}{ Larvae } \\
\hline & & No. & $\begin{array}{c}\text { Reduction } \\
\%\end{array}$ & No. & $\begin{array}{c}\text { Reduction } \\
\%\end{array}$ \\
\hline Check & - & $250.00 \mathrm{a}$ & - & $191.00 \mathrm{a}$ & - \\
\hline Gaucho & $\begin{array}{c}7 \mathrm{~g} / \mathrm{kg} \text { seeds } \\
14 \mathrm{~g} / \mathrm{kg} \text { seeds }\end{array}$ & $\begin{array}{l}91.50 \mathrm{~d} \\
50.00 \mathrm{e}\end{array}$ & $\begin{array}{l}63.40 \\
80.00\end{array}$ & $\begin{array}{l}58.00 \mathrm{~d} \\
26.25 \mathrm{e}\end{array}$ & $\begin{array}{l}69.63 \\
86.26\end{array}$ \\
\hline Diazinox 5\% G & $\begin{array}{l}4 \mathrm{~kg} \\
6 \mathrm{~kg}\end{array}$ & $\begin{array}{l}143.75 b \\
115.25 c\end{array}$ & $\begin{array}{l}42.50 \\
53.90\end{array}$ & $\begin{array}{l}93.25 \mathrm{~b} \\
80.25 \mathrm{bc}\end{array}$ & $\begin{array}{l}51.18 \\
57.98\end{array}$ \\
\hline Furazid $10 \%$ G & $\begin{array}{l}4 \mathrm{~kg} \\
6 \mathrm{~kg}\end{array}$ & $\begin{array}{c}129.50 \mathrm{~b} \\
105.75 \mathrm{~cd}\end{array}$ & $\begin{array}{l}48.20 \\
57.70\end{array}$ & $\begin{array}{l}100.25 b \\
80.25 b c\end{array}$ & $\begin{array}{l}47.51 \\
57.98\end{array}$ \\
\hline Furadan $10 \%$ G & $\begin{array}{l}4 \mathrm{~kg} \\
6 \mathrm{~kg}\end{array}$ & $\begin{array}{l}122.50 \mathrm{bc} \\
103.25 \mathrm{~cd}\end{array}$ & $\begin{array}{l}51.00 \\
58.70\end{array}$ & $\begin{array}{l}90.50 \mathrm{~b} \\
77.00 \mathrm{bc}\end{array}$ & $\begin{array}{l}52.62 \\
59.69\end{array}$ \\
\hline Bilarfuradan $10 \%$ & $\begin{array}{l}4 \mathrm{~kg} \\
6 \mathrm{~kg}\end{array}$ & $\begin{array}{l}115.75 \mathrm{c} \\
89.50 \mathrm{~d}\end{array}$ & $\begin{array}{l}53.70 \\
64.20\end{array}$ & $\begin{array}{l}73.50 \mathrm{c} \\
67.25 \mathrm{~cd}\end{array}$ & $\begin{array}{l}61.52 \\
64.79\end{array}$ \\
\hline
\end{tabular}

Means followed by the same letter are not significantly different at $5 \%$ level (DMRT)

Table (6): Effect of soil-incorporated and seed-coated insecticides on Pseudonapomyza spicata/5 maize plants during 10 July plantation (2011 season).

\begin{tabular}{|c|c|c|c|c|c|}
\hline \multirow{2}{*}{ Treatment } & \multirow{2}{*}{ Dose/fed } & \multicolumn{2}{|c|}{ Mines } & \multicolumn{2}{|c|}{ Larvae } \\
\hline & & No. & Reduction \% & No. & Reduction \% \\
\hline Check & - & $260.00 a$ & - & $175.50 \mathrm{a}$ & - \\
\hline Gaucho & $\begin{array}{c}7 \mathrm{~g} / \mathrm{kg} \text { seeds } \\
14 \mathrm{~g} / \mathrm{kg} \text { seeds }\end{array}$ & $\begin{array}{c}90.25 \mathrm{c} \\
68.25 \\
\end{array}$ & $\begin{array}{l}65.29 \\
73.75 \\
\end{array}$ & $\begin{array}{l}53.00 \mathrm{~d} \\
35.00 \mathrm{e}\end{array}$ & $\begin{array}{l}69.80 \\
80.06 \\
\end{array}$ \\
\hline Diazinox 5\% G & $\begin{array}{l}4 \mathrm{~kg} \\
6 \mathrm{~kg} \\
\end{array}$ & $\begin{array}{l}185.00 \mathrm{~b} \\
165.50 \mathrm{~b}\end{array}$ & $\begin{array}{l}28.85 \\
36.35 \\
\end{array}$ & $\begin{array}{l}98.50 \mathrm{~b} \\
87.25 \mathrm{c}\end{array}$ & $\begin{array}{l}43.88 \\
50.28 \\
\end{array}$ \\
\hline Furazid $10 \%$ G & $\begin{array}{l}4 \mathrm{~kg} \\
6 \mathrm{~kg}\end{array}$ & $\begin{array}{c}175.50 \mathrm{~b} \\
152.25 \mathrm{bc}\end{array}$ & $\begin{array}{l}52.81 \\
41.44 \\
\end{array}$ & $\begin{array}{c}85.50 \mathrm{c} \\
68.25 \mathrm{~cd}\end{array}$ & $\begin{array}{l}51.28 \\
61.11\end{array}$ \\
\hline Furadan $10 \%$ G & $\begin{array}{l}4 \mathrm{~kg} \\
6 \mathrm{~kg}\end{array}$ & $\begin{array}{c}171.25 \mathrm{~b} \\
153.00 \mathrm{bc}\end{array}$ & $\begin{array}{l}34.13 \\
41.15\end{array}$ & $\begin{array}{l}85.25 \mathrm{c} \\
61.25 \mathrm{~d}\end{array}$ & $\begin{array}{l}51.42 \\
65.10\end{array}$ \\
\hline Bilarfuradan $10 \%$ & $\begin{array}{l}4 \mathrm{~kg} \\
6 \mathrm{~kg}\end{array}$ & $\begin{array}{l}76.50 \mathrm{~d} \\
65.00 \mathrm{~d}\end{array}$ & $\begin{array}{l}70.58 \\
75.00\end{array}$ & $\begin{array}{c}79.75 \mathrm{c} \\
68.50 \mathrm{~cd}\end{array}$ & $\begin{array}{l}54.56 \\
60.97\end{array}$ \\
\hline
\end{tabular}

Means followed by the same letter are not significantly different at $5 \%$ level (DMRT)

\section{REFERENCES}

Abd El- Ghany, M. A. (2004). Studies on certain insects of maize at Kafr ElSheikh. Ph.D. Thesis, Fac. Agric., Kafr El Sheikh, Tanta Univ., 101 pp.

Abul-Nasr, S.; S. I. Sherif; A. L. Isa and A. S. Aly (1975). Efficiency of certain insecticides for the control of the maize leafminer, Pseudonapomyza spicata Mall. (Diptera: Agromyzidae). Agric. Res. Rev., 53: 81-85.

Aly, A. S. (1971). Studies on the biology, ecology and control of the maize leafminer, Pseudonapomyza spicata Mall. (Diptera: Agromyzidae) in U.A.R. M. Sc. Thesis, Fac. Agric., Cairo Univ., 110 pp.

Duncan, D. B. (1955). Multiple range and multiple F-test. Biometrics, 11: 1 124. 
El-Mashaly, N. R. A. (2009). Influence of some agronomic practices on the main insect pests infesting corn plants and their natural enemies. $M$. Sc. Thesis, Fac. Agric. Mansoura Univ., 141 pp.

FAO (1988). Amino acid content of food and biological data on proteins. Food and Agricultural Organization of the United Nation, Roma, Italy.

Haikal, A. A. (1969). Ecological and biological studies on the leafminer, Pseudonapomyza spicata Mall. (Agromyzidae: Diptera) attacking maize plants in U.A.R. M. Sc. Thesis, Fac. Agric., Ain Shams Univ., 105 pp.

Goad, R. T.; J. T. Goad; B. H. Atieh; R. C. Gupta (2004). "Carbofuraninduced endocrine disruption in adult male rats". Toxicology mechanisms and methods 14 (4): 233-9. doi: 10.1080/15376520490434476. PMID 20021136.

Tomlin, C. D. S. (2006). The Pesticide Manual, A World Compendium, 14th ed.; British Crop Protection Council: Surry, England; pp 598-599.

Wismer, T. (2004). Novel Insecticides. Clinical Veterinary Toxicology; Plumlee, K. H., Ed.; Mosby: St. Louis, MO; pp 184-185.

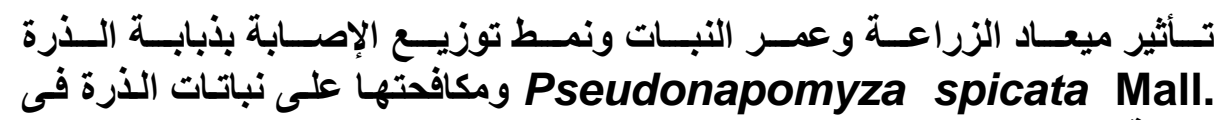
منطقة كفر الثيخ محمد السماحى ـ أحمد عبد الرحمن طمان ـ فتحية عبد الخالق سالم

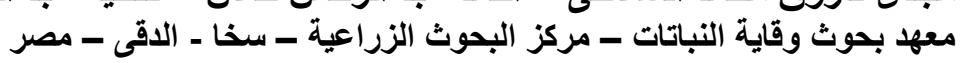

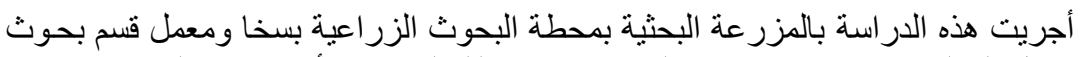

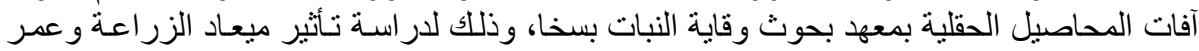

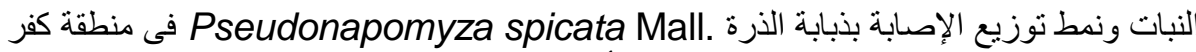

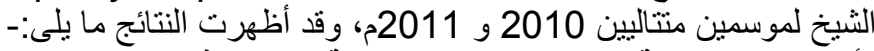

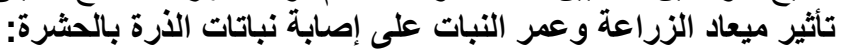

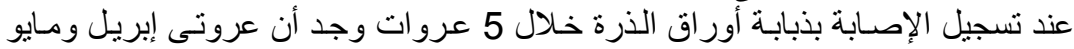

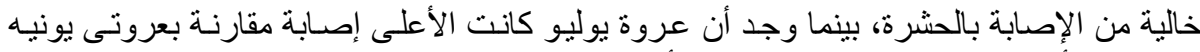

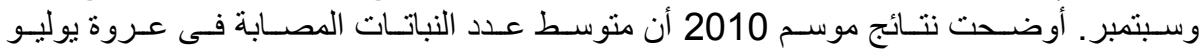

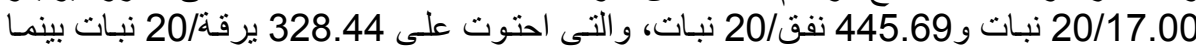

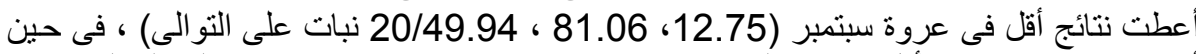

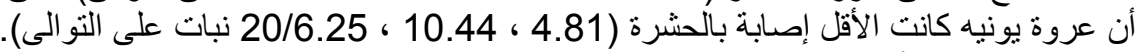

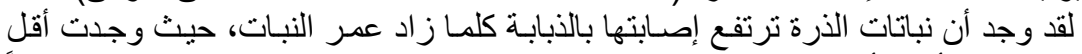

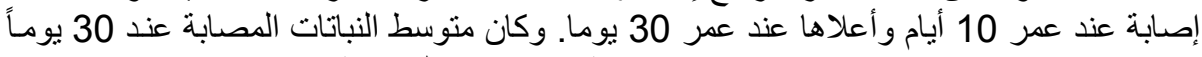

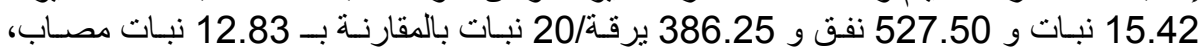

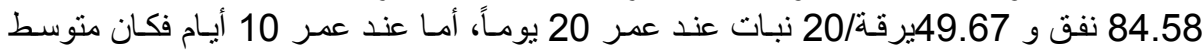

الإصابة بالذبابة 7.83 ، متوسط عدد الأنفاق 39.92 و متوسط عدد اليرقات 20/26.08 نبات.

نمط توزيع أنفاق ذبابة أوراق الذرة على أوراق نباتات الذرة: 
El-Samahy, M. F. M. et al.

أظهرت النتائج أن الأوراق السفلية كانت الأعلى إصـابة من حيث عدد الأنفاق (نفق/ورقة)

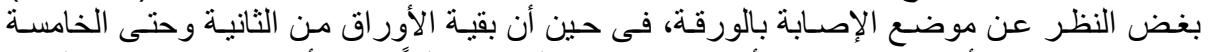

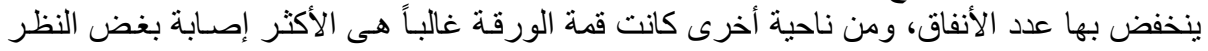

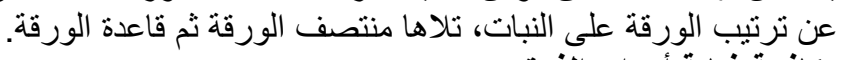

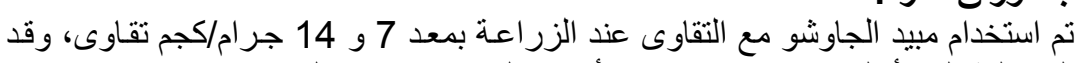

مكافحة ذبابة أوراق الذرة النبات

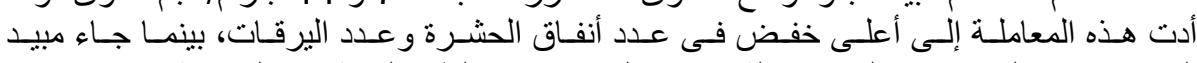
البيلافيور ادان المحبب فى المستوى الثانى ضد الحشى الحرة عند خلطه بالتربة عند الزر اعة.

كلية الزراعة - جامعة المنصورة قام بتحكيم البحث مركز البحوث الزراعية

\author{
أ.د / سمير البح صالح ابراهيم عوض الله \\ أ.د / محمود رمزى شريف اليف عوض
}

